\title{
Nuclear Expression of the 50- and 65-kD Rel-related Subunits of Nuclear Factor-kB Is Differentially Regulated in Human Monocytic Cells
}

\author{
Peter A. Kaufman," J. Brice Weinberg, ${ }^{\ddagger}$ and Warner C. Greene \\ ${ }^{*}$ Howard Hughes Medical Institute and ${ }^{* \pm}$ Division of Hematology/Oncology, ${ }^{\S}$ Department of Medicine, and ${ }^{\S}$ Department of Microbiology \\ and Immunology, Duke University Medical Center, Durham, North Carolina 27710
}

\begin{abstract}
The nuclear factor (NF)- $\kappa \mathrm{B}$ transcription factor system is composed of at least four inducible nucleoprotein adducts termed p50, p55 (NF-кB p50), p75 (NF-кB p65), and p85 (c-Rel). These proteins are expressed in the nuclei of activated $T$ cells in a distinctly biphasic fashion, with p55 and p75 induction occurring within minutes whereas the induction of p50 and p85 occurs after several hours. In contrast, p50 and p55 are constitutively expressed in the nuclei of U937 and THP-1 monocytic cells. However, cellular activation is required for the nuclear expression of p75 in these cells. Additionally, activation of monocytic cells does not result in a significant induction of $p 85$. Tumor necrosis factor $\alpha$ induces the nuclear expression of p55 and p75 in these monocytic cells within $20 \mathrm{~min}$, presumably reflecting the liberation of these proteins from IxB. In contrast, phorbol myristate acetate (PMA) induces the expression of these proteins with delayed kinetics, raising the possibility that PMA is incapable of mediating the efficient release of p55 and p75 from IxB in these cells. These findings highlight important differences in the regulation of these proteins in monocytic cells versus $T$ cells and suggest that the induced expression of NF$\boldsymbol{\alpha B}$ p65 in monocytes may play a central role in the activation of HIV-1 gene expression. (J. Clin. Invest. 1992. 90:121-129.) Key words: interferon- $\alpha \cdot$ monocytic cells $\bullet$ nuclear factor $\boldsymbol{\alpha B} \bullet$ transcriptional activation
\end{abstract}

\section{Introduction}

CD4+ T lymphocytes and CD4+ cells of the phagocytic mononuclear cell system, including circulating peripheral blood monocytes and extravascular tissue macrophages, appear to represent the major cellular targets for infection by the type 1 HIV (1-5). In sharp contrast to its lethal effects on T cells, HIV-1 exerts only minimal cytopathic effects on infected monocytic cells. Thus, these cells may serve as an important viral reservoir and as a cellular conduit for the spread of HIV-1 to other tissues of the body, including the central nervous system $(3,5,6)$. Various host transcription factors, notably members of the family of Rel-related $\kappa \mathrm{B}$ enhancer-binding proteins, have been shown to bind to and functionally activate the long termi-

Address reprint requests to Dr. Warner C. Greene, Gladstone Institute of Virology and Immunology, P.O. Box 419100, San Francisco, CA 94141-9100.

Received for publication 29 April 1991 and in revised form $13 \mathrm{De}$ cember 1991.

J. Clin. Invest.

(c) The American Society for Clinical Investigation, Inc.

0021-9738/92/07/0121/09 \$2.00

Volume 90, July 1992, 121-129 nal repeat (LTR) ${ }^{1}$ of HIV-1 (7-10). These host factors may thus play a critical role in the initial activation of HIV-1 gene expression that signals the transition from a latent, or persistent, form of infection to a high level of viral replication. The induction of these $\kappa \mathrm{B}$-specific DNA-binding proteins normally serves to regulate the expression of an array of cellular genes, including the $\kappa$ immunoglobulin light chain $(11,12)$, the $\alpha$ subunit of the IL-2 receptor (IL-2R $\alpha)(8,13-15)$, IL-2 (16), granulocyte-macrophage colony-stimulating factor $(17,18)$, and lymphotoxin (19).

Recent ultraviolet (UV)-crosslinking studies performed with phorbol ester-activated $\mathrm{T}$ cells revealed the presence of four inducible proteins giving rise to $\kappa \mathrm{B}$-specific nucleoprotein adducts termed p50, p55, p75, and p85 (8, 20, 21). The p55 adduct contains the $50-\mathrm{kD}$ subunit of nuclear factor (NF)- $\kappa \mathrm{B}$ (NF- $\mathrm{B}$ p50) (22-25) whereas p50 appears to correspond to a closely related gene product, perhaps a proteolytic fragment or alternatively spliced form of NF- $\kappa$ B p50 $(20,21)$. The p75 adduct contains the previously described $65-\mathrm{kD}$ subunit of NF- $\kappa \mathrm{B}$ (NF- $\kappa \mathrm{B}$ p65) (25-28) whereas p85 is composed of the c-rel proto-oncogene product (21). It is now clear that both the NF$\kappa \mathrm{B}$ p65 and c-Rel proteins can engage the $\kappa \mathrm{B}$ enhancer element in the absence of the smaller $\kappa \mathrm{B}$-specific DNA-binding proteins $(21,26,28)$. All four of these proteins have been found to share homology with the $v$-rel oncogene from the avian reticuloendotheliosis virus, REV T $(21,26,28-30)$. Of note, $v$-rel functions as a repressor of $\kappa \mathrm{B}$ enhancer-directed transcription in mature human $T$ cells (21). In phorbol ester-activated Jurkat $T$ cells, nuclear expression of these four proteins occurs in a distinctly biphasic manner with p55 (NF- $\kappa$ B p 50) and p75 (NF- $\kappa$ B p65) appearing in the nucleus within 20 min of phorbol ester activation whereas p50 and p85 (c-Rel) are detectable only after $\geq 4 \mathrm{~h}$ of activation (20). All of these proteins are detectable as preformed factors in $\mathrm{T}$ cells and are sequestered in the cytoplasm by an inhibitor likely identical to one or more of the forms of $I_{\kappa} B(20,21,24,25,31,32)$. However, in contrast to the early expression of p55 (NF- $k$ B p50) and p75 (NF- $\kappa$ B p65) in activated $T$ cells, the late nuclear expression of p50 and p85 (c-Rel) also involves a significant component of de novo synthesis of these proteins (20).

In this report, we compare and contrast the regulation of this Rel-related family of $\kappa \mathrm{B}$ enhancer-binding proteins in relatively mature (THP-1) and immature (U937) human monocytic cell lines with that previously reported in human Jurkat $T$ cells. We have detected a distinctly different pattern of expression of these proteins in these monocytic cells and now demon-

1. Abbreviations used in this paper: $\mathrm{BrdU}, 5^{\prime}$-bromo-2'-deoxyuridine 5 '-triphosphate; CAT, chloramphenicol acetyl transferase; IL-2R $\alpha, \alpha$ subunit of interleukin-2 receptor; LTR, long terminal repeat; NF, nuclear factor; TNF $\alpha$, tumor necrosis factor- $\alpha$. 
strate that NF- $\kappa$ B p50 is constitutively expressed in the nuclei of both U937 and THP-1 cells. In contrast, nuclear expression of NF- $\kappa$ B p65 requires cellular activation by such agents as tumor necrosis factor $\alpha(\mathrm{TNF} \alpha)$ or phorbol myristate acetate (PMA). Functionally, this induction in the nuclear expression of NF- $\kappa$ B p65 in both U937 and THP-1 cells is correlated with the transcriptional activation of the HIV-1 LTR. Furthermore, in contrast to the delayed, but marked, induction of p85 (c-Rel) in human Jurkat $\mathrm{T}$ cells, little increase in the nuclear expression of this proto-oncogene product occurs in activated U937 or THP-1 monocytic cells. Finally, we demonstrate that the kinetics of TNF $\alpha$ and PMA induction of these various $\kappa B$ enhancer-binding proteins are very different in these monocytic cells compared with human Jurkat $\mathrm{T}$ cells. Specifically, we have found that TNF $\alpha$ stimulates the rapid nuclear translocation ( $\leq 20 \mathrm{~min}$ ) of NF- $\kappa \mathrm{B}$ p50 and NF- $\kappa$ B p65 in both of these human monocytic cell lines (U937 and THP-1). In contrast, PMA promotes only a delayed nuclear expression of these factors in both U937 and THP-1 monocytic cells, suggesting that this tumor promoter may fail to mobilize these preformed cytoplasmic factors for transport to the nucleus in these cells, but may act by inducing their de novo synthesis.

\section{Methods}

Cell lines and nuclear extract preparation. The human promonocytic U937 cell line (33) and the relatively mature human monocytic THP-1 cell line (34) were obtained from the American Type Culture Collection (ATCC, Rockville, MD) and were cultured in RPMI 1640 medium supplemented with $7.5 \%$ FCS, $2 \mathrm{mM}$ L-glutamine, $100 \mathrm{U} / \mathrm{ml}$ penicillin, and $100 \mu \mathrm{g} / \mathrm{ml}$ streptomycin. U937 and THP-1 cells were routinely grown to a density of 4-8 $\times 10^{5}$ and 3-6 $\times 10^{5}$ cells $/ \mathrm{ml}$, respectively. Human Jurkat $T$ cells were grown under similar conditions as the U937 cells. Based on several parameters, the U937 cells correspond to relatively immature monocytic cells whereas the THP-1 cells represent a more mature population of cells (33-35). THP-1 cells grow less rapidly than U937 cells, with doubling times of 37 and $17 \mathrm{~h}$, respectively. Compared with U937 cells, the THP-1 cells express significantly higher levels of select membrane antigens consistent with a more mature, or differentiated, cellular phenotype. Specifically, indirect immunofluorescence staining and analysis on a fluorescence-activated cell sorter has revealed the following percent positive cells for the THP1 and U937 cell lines, respectively: OKM1 (CD 11b) 75\% and 38\%, LeuM3 (CD 14) $20 \%$ and $2 \%$, and HLA-DR $62 \%$ and $8 \%$.

Cell populations were stimulated with either phorbol 12-myristate 13-acetate (PMA) at a final concentration of $50 \mathrm{ng} / \mathrm{ml}$ or TNF $\alpha$ (Genzyme Corp., Boston, MA), at final concentrations generally ranging between 10 and $100 \mathrm{U} / \mathrm{ml}$. Nuclear extracts were prepared at various times after stimulation as previously described $(20,36,37)$, using aliquots of $3-10 \times 10^{7}$ cells, with the following modifications:

(a) All steps in the nuclear extraction procedure were performed at $4^{\circ} \mathrm{C}$.

(b) The hypotonic lysis buffer (buffer I) contained the following (mM): 10 Hepes (pH 7.9), $1.5 \mathrm{MgCl}_{2}, 10 \mathrm{KCl}, 0.1$ EGTA, and 0.5 dithiothreitol. $0.5 \mathrm{mM}$ phenylmethylsulfonyl fluoride, $0.5 \mathrm{mg} / \mathrm{ml}$ antipain, $0.5 \mathrm{mg} / \mathrm{ml}$ aprotinin, $0.5 \mathrm{mg} / \mathrm{ml}$ leupeptin, $0.05 \mathrm{mg} / \mathrm{ml}$ pepstatin, and $0.5 \mathrm{mg} / \mathrm{ml}$ soybean trypsin inhibitor were also added to both the hypotonic lysis buffer and all subsequent buffers used during the preparation of the nuclear extracts.

(c) The cell pellet wash in buffer I was omitted, and the cell pellet was resuspended in $\sim 5 \mathrm{vol}$ of buffer I before homogenization with a loose-fitting Dounce homogenizer (Fisher Scientific Co., Pittsburgh, PA). Nuclei were collected by centrifugation at 3,000 rpm for 5 min in an Eppendorf microfuge (Brinkmann Instruments Inc., Westbury, NY).

(d) The nuclear pellet wash in buffer I after Dounce homogeniza- tion was omitted, and the nuclear pellet obtained after cell lysis was resuspended in $\sim 2.5$ vol of buffer II ( $20 \mathrm{mM}$ Hepes, $25 \%$ glycerol, 0.3 $\mathrm{M} \mathrm{KCl}, 1.5 \mathrm{mM} \mathrm{MgCl}, 0.2 \mathrm{mM}$ EDTA, $0.1 \mathrm{mM}$ EGTA, $0.5 \mathrm{mM}$ PMSF, 0.5 mM DTT).

Oligonucleotide preparation. Oligonucleotides were synthesized on a DNA synthesizer (Applied Biosystems, Foster City, GA) and cleaved with ammonia. These synthetic DNAs were recovered using oligonucleotide purification cartridges (Applied Biosystems) and further enriched by preparative PAGE.

Gel retardation and UV-crosslinking analysis. Double-stranded photoreactive ${ }^{32} \mathrm{P}$-radiolabeled oligonucleotide probes containing the $\kappa B$ enhancer element were prepared as previously described $(15,20$, 38). Briefly, a 27-nucleotide single strand spanning the plus strand $\kappa \mathrm{B}$ enhancer element of the IL-2R $\alpha$ gene (5' CAACGGCAGGGGAATCTCCCTCTCCTT $3^{\prime}$ ) was annealed to a complementary 10-bp primer, followed by primer extension with the Klenow fragment of DNA polymerase I in the presence of 5 '-bromo-2'-deoxyuridine 5 ' triphosphate $(\mathrm{BrdU})$ and $\left[\alpha-{ }^{32} \mathrm{P}\right]$ deoxynucleoside triphosphates. Gel retardation assays were performed as previously described using this photoreactive probe, and DNA-protein complexes were separated from the free DNA probe by electrophoresis through low ionic strength 5\% polyacrylamide gels (8). UV-crosslinking was performed in solution by irradiating the respective nuclear extract and ${ }^{32} \mathrm{P}-\mathrm{BrdU} \kappa \mathrm{B}$ oligonucleotide probe with a $300-\mathrm{nM}$ UV light source $(7000 \mathrm{~mW} / \mathrm{cm}$ illuminator, Fotodyne Inc., New Berlin, WI) for $20 \mathrm{~min}$ and then analyzing the UV-crosslinked adducts directly on discontinuous SDS 7.5\% polyacrylamide gels electrophoresed under reducing conditions.

Transient DNA transfection and chloramphenicol acetyl transferase assays. U937 and THP-1 cells cultured as described above were transiently transfected with previously described reporter plasmids containing either the HIV-1 LTR (position -633 to +80 relative to the start of transcription) linked to the bacterial chloramphenicol acetyl transferase (CAT) gene (HIV-LTR CAT) or an identical construct containing a 3-bp substitution mutation in both $\kappa$ B-enhancer elements (GGG $\rightarrow$ CTC) $(\Delta x$ B HIV-LTR CAT) (39). These plasmids were introduced using a standard DEAE-dextran transfection procedure (40) modified by the omission of exposure to chloroquine. Briefly, $5 \times 10^{6}$ U937 cells or $7.5 \times 10^{6} \mathrm{THP}-1$ cells were transfected with $1-3 \mu \mathrm{g}$ of plasmid DNA, and selected cultures were stimulated with either 50 $\mathrm{ng} / \mathrm{ml}$ PMA or $100 \mathrm{U} / \mathrm{ml} \mathrm{TNF} \alpha$ after $18-24 \mathrm{~h}$ of culture. CAT activity was assayed $36-48 \mathrm{~h}$ after transfection (41). Results are shown as the mean fold increase of CAT activity relative to the response obtained with media alone. All values were normalized for total protein recovery as determined by the Bradford colorimetric assay (42). Percent conversion of chloramphenicol to ${ }^{3} \mathrm{H}$-acetyl chloramphenicol was calculated using a value of $100 \%$ for the activity obtained with the addition of 0.5 $\mathrm{U}$ of purified CAT (Boehringer Mannheim Biochemicals, Indianapolis, IN).

\section{Results}

The pattern of expression of the family of $\alpha B$ enhancer-binding proteins in the U937 and THP-1 monocytic cell lines was first investigated using gel retardation assays. Nuclear extracts prepared from unstimulated promonocytic U937 cells revealed the constitutive expression of one or more $\kappa \mathrm{B}$ enhancer-binding proteins mediating the formation of a relatively rapidly migrating nucleoprotein complex designated $\mathrm{B} 2$ (Fig. $1 \mathrm{~A}$, lane 1). The addition of a 100 -fold molar excess of unlabeled wildtype competitor $(\kappa \mathrm{B}-\mathrm{WT})$, but not unlabeled mutant competitor lacking the $\kappa \mathrm{B}$ enhancer sequences $(\Delta \kappa \mathrm{B})$, blocked the formation of this B2 complex thus confirming the sequence-specific nature of this DNA-protein interaction (Fig. $1 \mathrm{~A}$, lanes 2 and 3). Activation of these U937 cells with TNF $\alpha$ resulted in the induced nuclear expression of one or more new $\kappa B$ enhancer-binding proteins that mediated the formation of a 


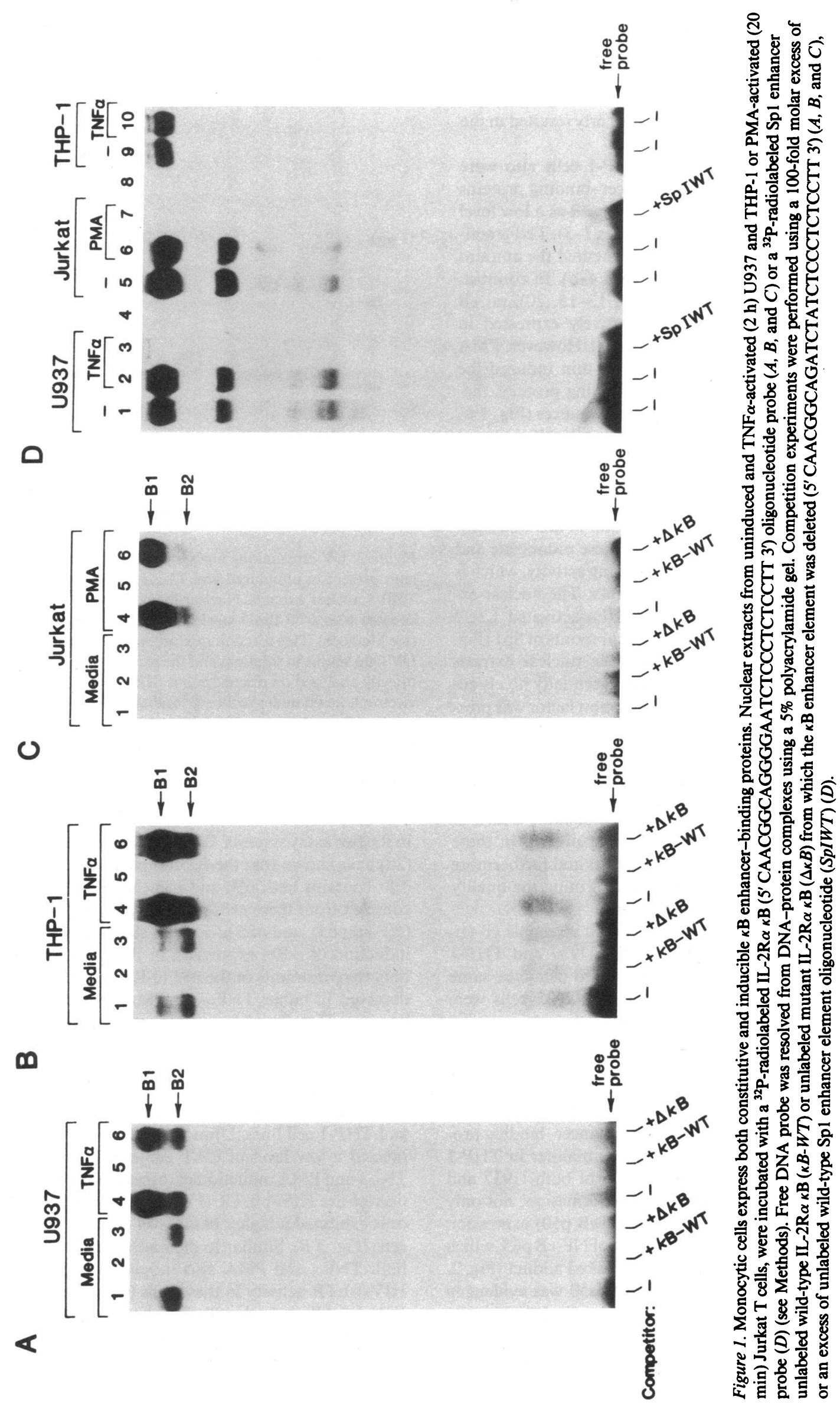


slower electrophoretic mobility complex, designated B1 (Fig. 1 $A$, lane 4). Competition experiments using unlabeled wild-type and mutant- $\kappa \mathrm{B}$-enhancer elements again confirmed the specific nature of these DNA-protein interactions (Fig. $1 A$, lanes 5 and 6). PMA activation of U937 cells similarly resulted in the induction of the B1 complex (see below).

The phenotypically more mature THP-1 cells also were found to constitutively express $\kappa \mathrm{B}$ enhancer-binding proteins mediating formation of the B2 complex, as well as a low level expression of the B1 complex (Fig. $1 B$, lanes 1-3). TNF $\alpha$ activation of these THP-1 cells markedly augmented the amount of this specific B1 complex (Fig. $1 \mathrm{~B}$, lanes 4-6). In contrast, and in agreement with earlier studies $(7,13-15,20)$, no $\kappa \mathrm{B}$ enhancer-binding proteins were constitutively expressed in uninduced Jurkat T cells (Fig. $1 C$, lanes $1-3$ ). However, PMA activation of these Jurkat cells for only $20 \mathrm{~min}$ induced the nuclear expression of the $\kappa \mathrm{B}$ enhancer-binding proteins mediating formation of both the B2 and B1 complexes (Fig. $1 C$, lane 4). Similarly, TNF $\alpha$ activation of Jurkat T cells induced both B2 and B1 complex formation (data not shown).

In addition to its duplicated $\kappa \mathrm{B}$ enhancer elements, the HIV-1 LTR contains a triplet of adjacent Spl sites that are importantly required for the normal function of this transcription unit (43). The nuclear extracts from these monocytic and $\mathrm{T}$ cell lines were also analyzed for $\mathrm{Sp} 1$ binding activity, which is normally expressed in a constitutive manner. The nuclear extracts isolated from unstimulated or TNF $\alpha$-activated U937 cells contained virtually indistinguishable amounts of Sp1 (Fig. $1 D$, lanes 1-3). Additionally, whereas the nuclear extracts from uninduced Jurkat T cells contained essentially no $\kappa$ B-enhancer-binding proteins, the $\mathrm{Sp} 1$ transcription factor was present in amounts comparable to that found in PMA-induced Jurkat cells (Fig. 1 D, lanes 5-7) as well as in uninduced and induced U937 cells. Unstimulated and TNF $\alpha$-activated THP-1 nuclear extracts also contained similar quantities of SpI (Fig. 1 $D$, lanes 9 and 10). These results thus demonstrate a lack of induction of an independent DNA-binding protein in these unstimulated and stimulated nuclear extracts and furthermore provide an important internal control confirming the quality of the various nuclear extract preparations.

To characterize both the constitutive and inducible $\kappa \mathrm{B}$-enhancer-binding proteins expressed in the U937 and THP-1 cells, UV-crosslinking studies were performed using the same extracts employed in Fig. 1. Unstimulated U937 cells were found to constitutively express in their nuclei proteins giving rise to both the p50 and p55 adducts (Fig. 2, lanes 1-3). Although the protein component of $\mathrm{p} 50$ proved to be the major constitutively expressed $\kappa \mathrm{B}$-enhancer-binding protein in U937 cells, the p55 adduct (NF- $\kappa$ B p50) was consistently detected. These same lower molecular weight $\kappa \mathrm{B}$ enhancer-binding proteins were also expressed in a constitutive manner in THP-1 cells (Fig. 2, lanes 7-9). TNF $\alpha$ activation of both U937 and THP-1 cells, which induced B1 complex formation, not only resulted in a marked increase in p55 (NF- $\kappa$ B p50) expression but also in the de novo nuclear expression of NF- $k$ B p65, which mediates the formation of the p75 crosslinked adduct (Fig. 2, lanes 4 and 10). No further induction of p50 was evident in either the TNF $\alpha$-activated U937 or THP-1 cells. Interestingly, UV-crosslinking analyses of uninduced THP-1 nuclear extracts did not reveal the presence of p75 (NF- $\kappa$ B p65), although small amounts of the $B 1$ complex were evident in the gel retardation assay. This finding may be due to different sensitivities

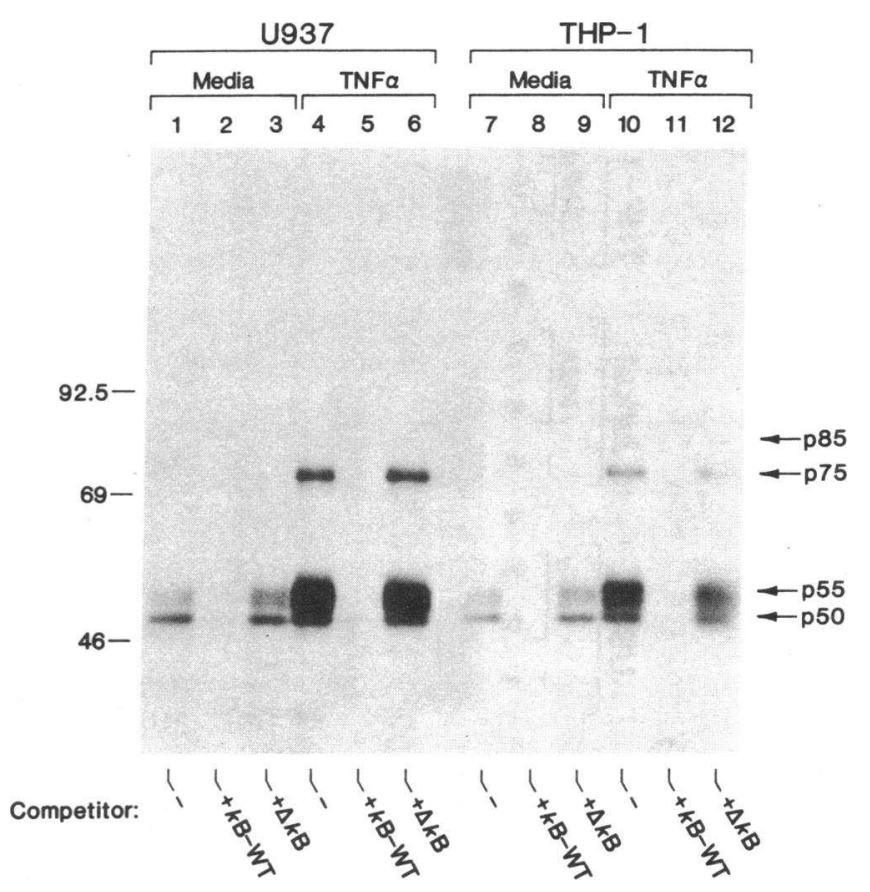

Figure 2. UV-crosslinking analyses of $\mathrm{kB}$-specific DNA-binding proteins present in uninduced and TNF $\alpha$-activated $(2 \mathrm{~h}) \mathrm{U} 937$ and THP-1 nuclear extracts. Nuclear extracts (15-20 $\mu \mathrm{g}$ protein) were incubated with a ${ }^{32} \mathrm{P}$-BrdU-labeled IL-2R $\alpha \kappa \mathrm{B}$ oligonucleotide probe (see Methods). This reaction mixture was irradiated under a $300 \mathrm{nM}$ UV light source in solution, and the resultant UV-crosslinked adducts directly analyzed on discontinuous SDS $7.5 \%$ polyacrylamide gels electrophoresed under reducing conditions. Competition experiments were performed using a 100 -fold molar excess of unlabeled $\kappa \mathrm{B}-\mathrm{WT}$ or $\Delta \mathrm{xB}$ oligonucleotides (see Fig. 1 legend). The migration of each UV-crosslinked adduct ( $p 50, p 55$ [NF- $\kappa$ B p50], $p 75$ [NF- $\kappa$ B-p65], and $p 85$ [c-Rel]) is indicated by the arrows.

in the two assay systems. Earlier in situ UV-crosslinking studies (20) have shown that the B2 complex from activated Jurkat T cells contains both $\mathrm{p} 50$ and $\mathrm{p} 55$ (NF- $\mathrm{B}$ p50) whereas the B1 complex from these cells contains p50, p55 (NF- $\kappa$ B p50), p75 (NF- $\kappa \mathrm{B}$ p65), and p85 (c-Rel). In sharp contrast to the marked induction of c-Rel expression in PMA-activated T cells (20), only trace amounts of the p85 (c-Rel) crosslinked adduct were observed in either TNF $\alpha$ - or PMA-activated monocytic cell lines (see Figs. 2 and 6, and data not shown).

To evaluate the functional consequences of the induced nuclear expression of NF- $\kappa$ B p65 in these monocytic cells, we analyzed both the basal and TNF $\alpha$ - or PMA-induced activity of HIV-LTR CAT reporter plasmids transfected into the U937 and THP-1 cell lines. Uninduced U937 cells constitutively expressed a low level of CAT enzyme activity, however, both TNF $\alpha$ and PMA induction of these cells led to marked stimulation of the HIV-1 LTR (Fig. $3 A$ ). The more mature THP-1 cells exhibited a higher basal level of CAT activity than U937 cells (Fig. 3 B). Similar to the findings in U937 cells, however, both TNF $\alpha$ and PMA also induced a 5-10-fold increase in HIV-1 LTR activity in these cells (Fig. $3 \mathrm{~B}$ ). Activation of the HIV-1 LTR in both cell lines importantly involved protein interactions at the $\kappa \mathrm{B}$ enhancer, as an HIV-LTR CAT construct containing mutant $\kappa B$ enhancer elements $(\Delta \kappa B$ HIVLTR CAT) exhibited markedly reduced activity in response to either TNF $\alpha$ or PMA (Fig. $3 A$ and $B$ ). 
A

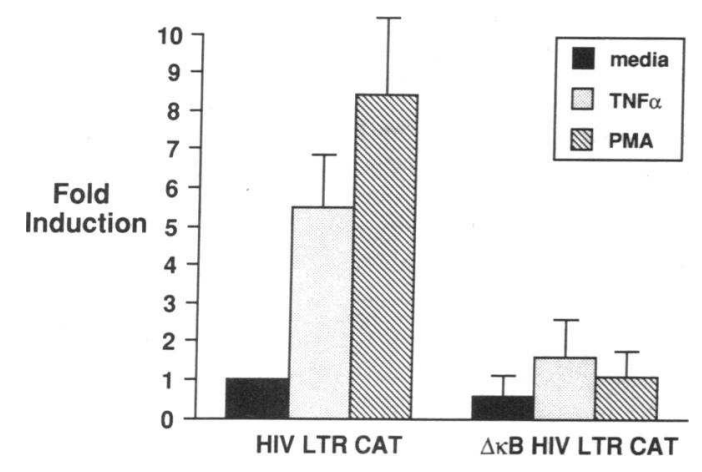

B

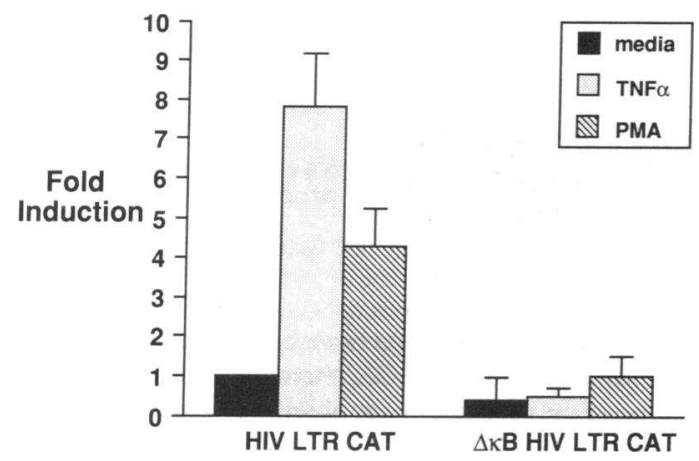

Figure 3. TNF $\alpha$ or PMA activation of monocytic cells induces the expression of HIV LTR CAT. U937 cells $(A)$ or THP-1 cells $(B)$ were transiently transfected with either HIV LTR CAT or $\triangle \kappa B$ HIV LTR CAT plasmids and selected cultures were activated with either TNF $\alpha$ or PMA (see Methods). These results represent the mean of three to five independent experiments, with the error bars representing the SD. The basal level of CAT activity, as measured by percent conversion of chloramphenicol to ${ }^{3} \mathrm{H}$-acetyl chloramphenicol relative to purified CAT enzyme (see Methods) and normalized for protein concentration was $0.3 \pm 0.1 \%$ for HIV LTR CAT-transfected U937 cells, whereas the basal level for HIV LTR CAT-transfected THP-1 cells was $5.9 \pm 2.3 \%$.

The dose-response relationship for the TNF $\alpha$ induction of the NF- $\kappa$ B p65-dependent $B 1$ complex formation in U937 cells was next investigated (Fig. 4). TNF $\alpha$ concentrations ranging from 10 to $500 \mathrm{U} / \mathrm{ml}$ effectively induced the appearance of the B1 complex, with a maximal response being noted at $10 \mathrm{U} / \mathrm{ml}$. Concentrations of TNF $\alpha$ as low as $1 \mathrm{U} / \mathrm{ml}$ induced a small but consistent increase in B1 complex formation. This dose-response curve for TNF $\alpha$ falling between 1 and $10 \mathrm{U} / \mathrm{ml}$ is within the range of this cytokine seen in various pathophysiological conditions $(44,45)$.

We next analyzed the kinetics of TNF $\alpha$ and PMA induction of these $\kappa \mathrm{B}$ enhancer-binding proteins in U937 cells. Similar to its effects on T cells, TNF $\alpha$ rapidly induced B1 complex formation in the U937 monocytic cells, with a detectable response occurring within $20 \mathrm{~min}$ (Fig. $5 \mathrm{~A}$ ). However, in sharp contrast, PMA activation required between 2 and $4 \mathrm{~h}$ to induce B1 complex formation in these U937 cells (Fig. 5 B). These latter results differ markedly from the rapid kinetics of induc-

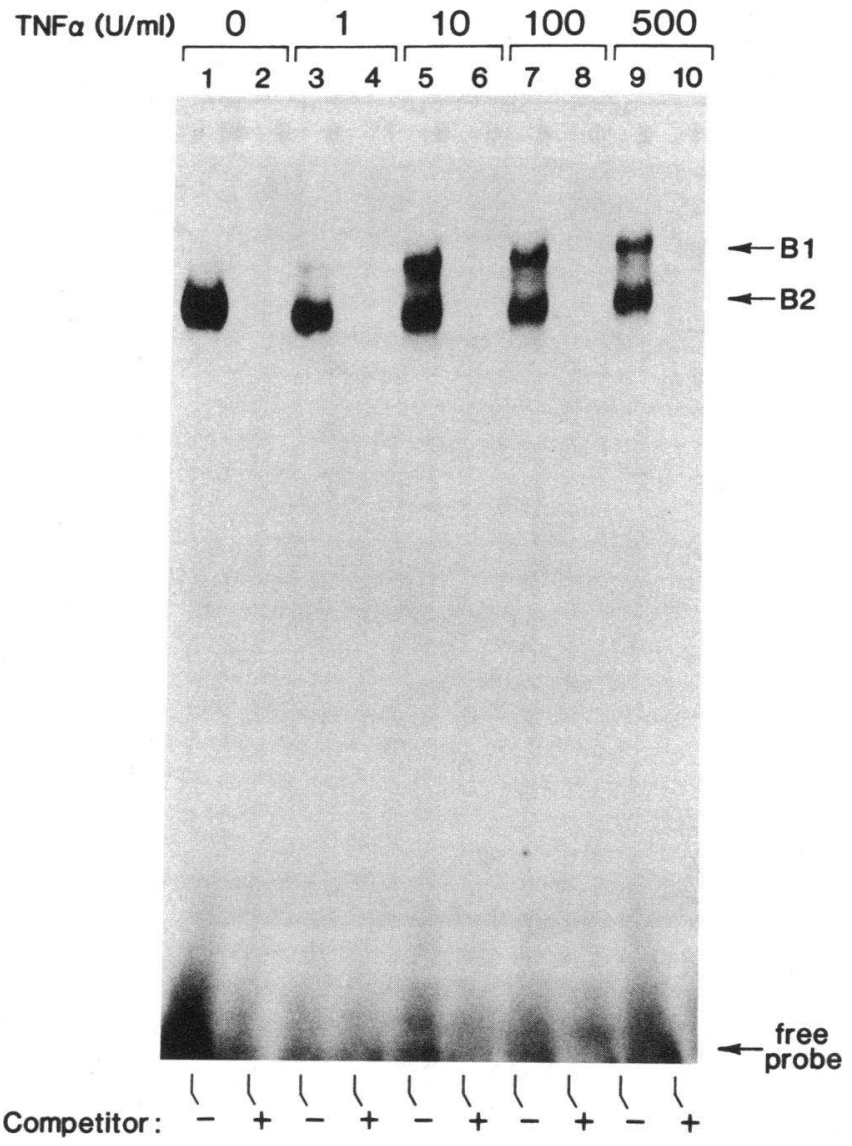

Figure 4. Dose-response relationship for TNF $\alpha$ induction of $\kappa \mathrm{B}$ enhancer-binding proteins in U937 cells. Nuclear extracts were isolated from U937 cells incubated in media alone or TNF $\alpha(1-500 \mathrm{U} / \mathrm{ml})$. Gel retardation assays were then performed with a ${ }^{32} \mathrm{P}$-radiolabeled IL-2R $\alpha \kappa B$ enhancer probe in the presence $(+)$ or absence $(-)$ of a 100-fold excess of unlabeled wild-type competitor oligonucleotide. The B1 and B2 nucleoprotein complexes and free radiolabeled probe are indicated by arrows.

tion found with PMA in human Jurkat T cells (Fig. 1C) (20). Similar to the response in U937 cells, in THP-1 cells TNF $\alpha$ induced a rapid B1 complex formation whereas PMA exhibited the same slow kinetics of induction (data not shown). UVcrosslinking studies demonstrated that the rapid TNF $\alpha$ induction of the B1 complex in U937 cells correlated with the rapid induction of both p55 (NF- $\kappa$ B p50) and p75 (NF- $\kappa$ B p65) (Fig. $6 \mathrm{~A}$ ). Similarly, the delayed induction of B1 by PMA in these cells also correlated with the delayed induction of $\mathrm{p} 55$ (NF- $\kappa \mathrm{B}$ p50) and p75 (NF- $\mathrm{kB} \mathrm{p65)} \mathrm{(Fig.} 6$ B). In further contrast to the effects of PMA on Jurkat T cells (20), p85 (c-Rel) was not significantly induced by either TNF $\alpha$ or PMA in U937 or THP-1 monocytic cells (Fig. 6, $A$ and $B$ ).

\section{Discussion}

In this study we have explored the pattern of expression of the Rel-related family of $\alpha \mathrm{B}$-enhancer-binding proteins in the relatively immature U937 and the relatively mature THP-1 human monocytic cell lines and contrasted these findings with those previously observed in human Jurkat $\mathrm{T}$ lymphocytes ( 7 , 


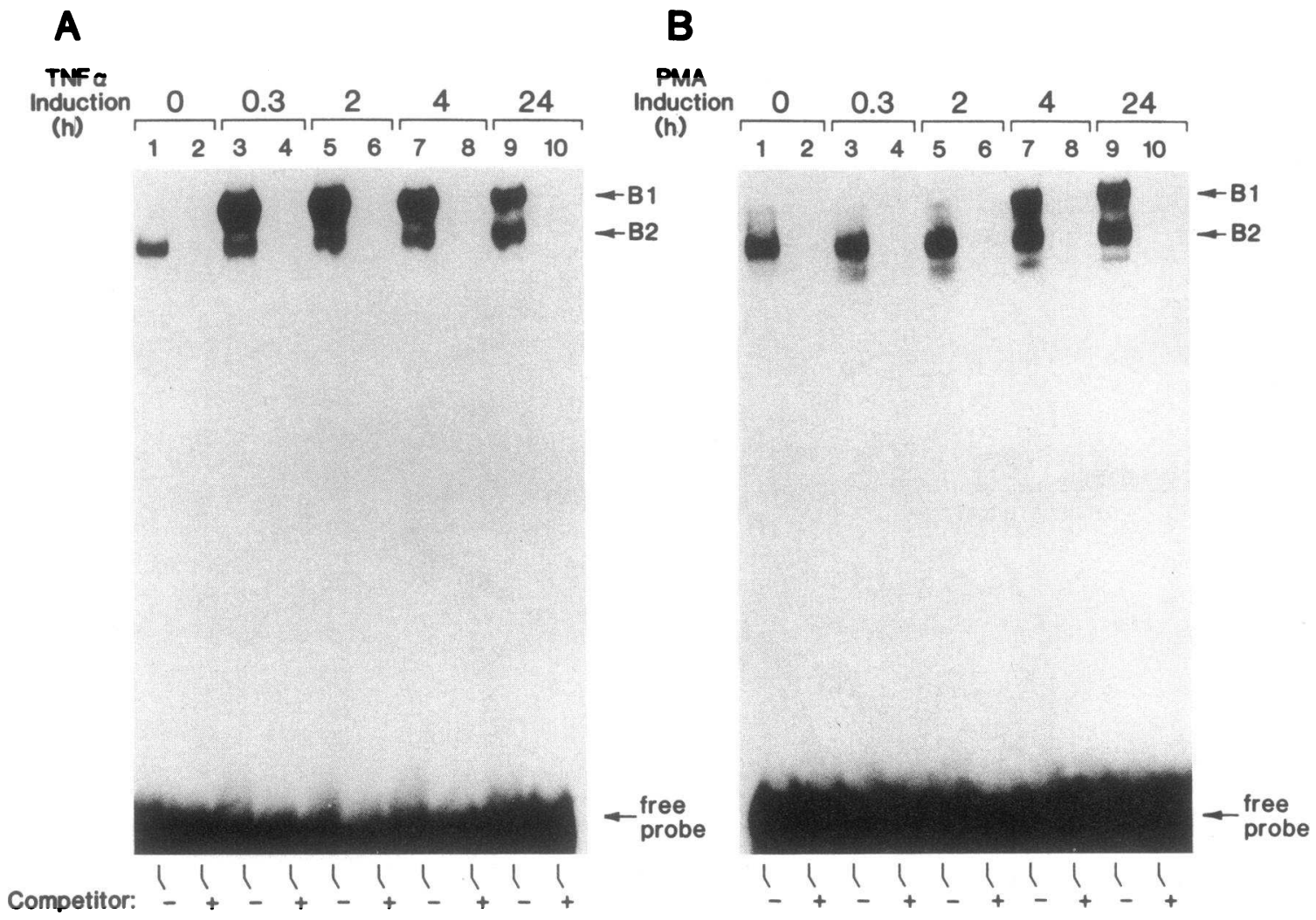

Figure 5. Time course of TNF $\alpha$ and PMA induction of $\kappa$ B enhancer-binding proteins in U937 cells. Nuclear extracts were prepared from U937 cells after activation with either TNF $\alpha(10 \mathrm{U} / \mathrm{ml})(A)$ or PMA $(50 \mathrm{ng} / \mathrm{ml})(B)$ for the indicated lengths of time. Gel retardation assays were performed with $10 \mu \mathrm{g}$ of nuclear protein and ${ }^{32} \mathrm{P}$-radiolabeled IL-2R $\alpha \mathrm{kB}$ oligonucleotide probe in the presence $(+)$ or absence $(-)$ of a $100-$ fold excess of unlabeled competitor oligonucleotide.

A

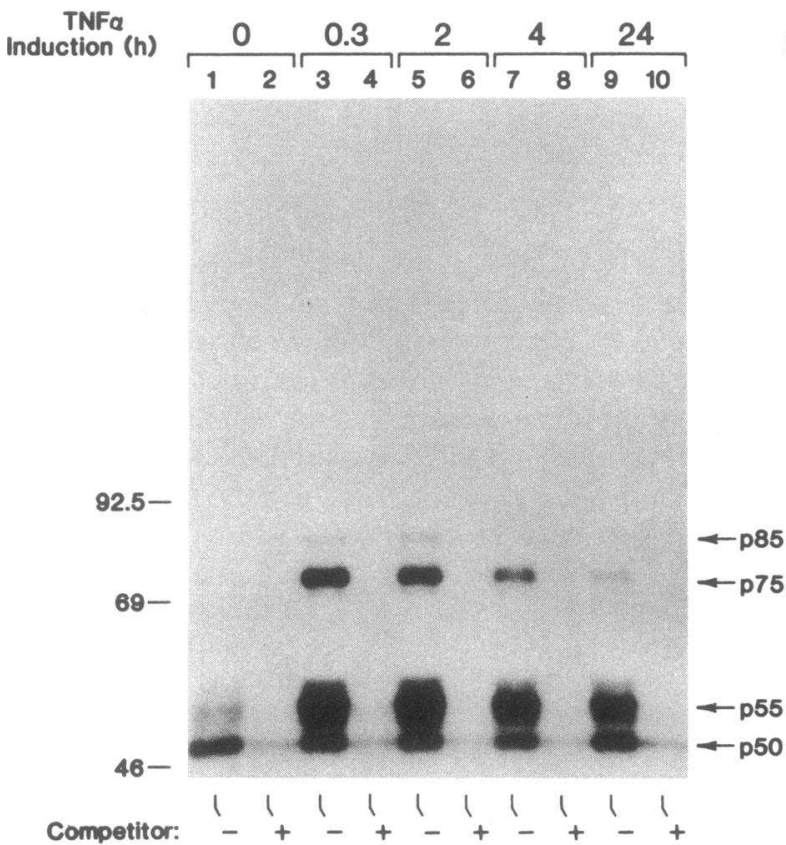

B

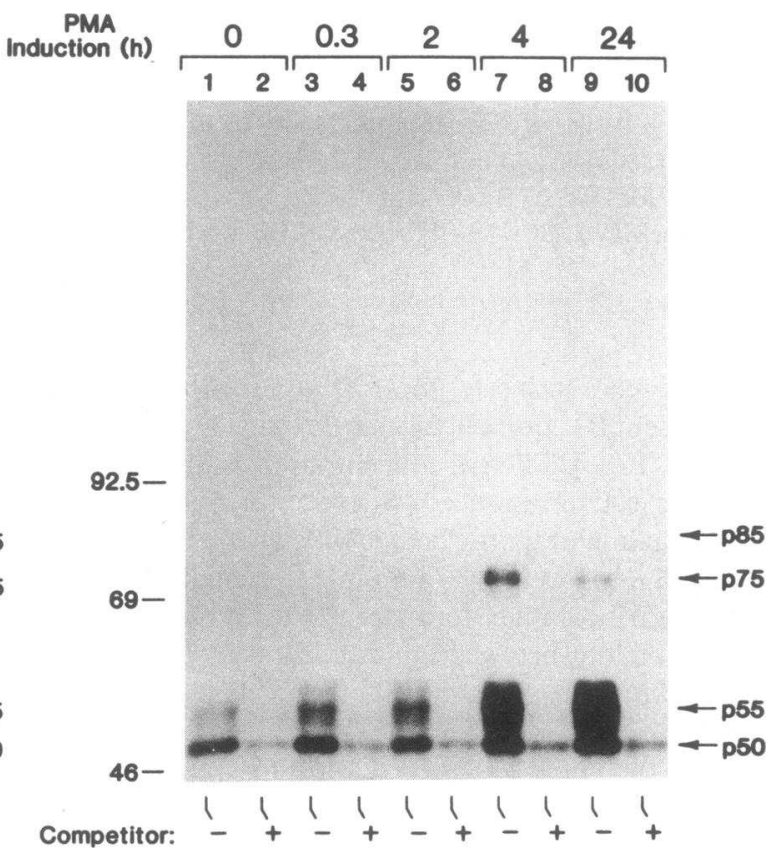

Figure 6. UV-crosslinking analysis of the kinetics of TNF $\alpha$ and PMA induction of $\kappa$ B enhancer-binding proteins in U937 cells. The same nuclear extracts described in Fig. 5 from U937 cells induced with TNF $\alpha(A)$ or PMA $(B)$ were incubated with a ${ }^{32}$ P-radiolabeled BrdU-substituted IL-2R $\alpha$ $\kappa \mathrm{B}$ oligonucleotide probe. The reaction mixtures were then irradiated with UV light in solution and analyzed on a discontinuous SDS 7.5\% polyacrylamide gel (see Fig. 2 legend). Competition experiments were performed in the presence $(+)$ or absence ( - ) of a 100-fold molar excess of unlabeled wild-type IL-2R $\alpha$ BB. The migration positions of p50, p55 (NF- $\mathrm{B}$ p50), p75 (NF-kB p65), and p85 (c-Rel) are indicated. 
$9,13,20,46-48)$. These studies were performed with the hope of providing new information bearing on the nature of the pathogen-host interaction of HIV-1 with monocytes.

Before discussing the important differences detected in the pattern of $\kappa \mathrm{B}$-enhancer-binding protein expression in these monocytic cells, it is appropriate to review the evolution of our understanding of NF- $\kappa$ B DNA-binding activity, which in fact corresponds to a multigene family encoding structurally related gene products. Early studies suggested that the $\kappa \mathrm{B}$ enhancer, now identified in several inducible cellular and viral transcription units including the HIV-1 LTR $(7,8,11-15,17$, 18 ), is engaged by a single $50-\mathrm{kD}$ polypeptide termed NF- $\kappa \mathrm{B}$ p50 which in turn is associated with a 65-kD non-DNA-binding subunit (p65) $(24,25,29-31)$. Both the 50 - and the $65-\mathrm{kD}$ subunits of NF- $\kappa \mathrm{B}$ are constitutively expressed in a broad array of cells, however, constitutive nuclear DNA-binding activity occurs in only a few cell types, notably mature B cells $(11,47$, 48). In most other cells, the preformed NF- $\kappa B$ p 50 and NF- $\kappa B$ p65 polypeptides are complexed with a cytoplasmic inhibitor, termed $I_{\kappa} \mathrm{B}$, which inhibits both the nuclear expression and DNA-binding activity of the complex $(24,31,48)$. This interaction with $I_{\kappa} B$ appears to be mediated through the NF- $\kappa B$ p 65 subunit, which thus can be viewed as the cellular receptor for I $\kappa B(25)$. Cellular activation by a variety of stimulants promotes the disassembly of this complex, perhaps as a consequence of phosphorylation of $I_{\kappa} B(32)$. This disassociation in turn allows the rapid translocation of the NF- $\kappa \mathrm{B} / \mathrm{p} 65$ complex to the nucleus $(13,14,32,46,49,50)$. It has been proposed that this complex exists as a heterotetramer (25), although more recent data are consistent with a heterodimeric structure (21). Strikingly, molecular cloning of human and murine NF- $k$ B p50 and NF- $\mathrm{kB}$ p 65 cDNAs has revealed structural homology of these proteins with the $v$-rel oncogene and the dorsal gene of Drosophila, which functions as a maternal morphogen $(26,28-$ 30 ). Further, these studies have demonstrated that NF- $\kappa$ B p 65 alone exhibits DNA-binding activity specific for the $\kappa \mathrm{B}$ enhancer $(26,28)$. More recently, we have found that the NF- $\kappa$ B p65 subunit contains a potent transcription activation domain near its carboxy terminus whereas NF- $\kappa$ B p50 appears to lack such an activity (27).

Independent UV-crosslinking studies have revealed an even more complex array of $\kappa \mathrm{B}$ enhancer-binding proteins in human $\mathrm{T}$ cells and $\mathrm{HeLa}$ epithelial cells. Specifically, four UVcrosslinked adducts ( $p 50, \mathrm{p} 55, \mathrm{p} 75$, and $\mathrm{p} 85$ ) have been identified $(8,15,20,21)$. All of the protein components of these adducts appear structurally related to the $v$-rel oncogene product, based on their specific immunoreactivity with anti-v-Rel antibodies (21). As noted above, the p85 adduct has now been shown to correspond to the $82-\mathrm{kD}$ c-rel proto-oncogene product (21), while p55 and p 75 correspond to NF- $\kappa$ B p50 and NF- $\kappa$ B p65, respectively $(21,26-28)$. These four adducts are expressed in an inducible but temporally biphasic manner in Jurkat T cells (20). Specifically, within minutes after PMA activation of Jurkat cells, the p55 (NF- $\kappa$ B p50) and p75 (NF- $\kappa$ B p65) adducts are detectable in the nucleus (20). In addition to p55 (NF- $\kappa$ B p50) and p75 (NF- $\kappa$ B p65), which form a heteromeric complex migrating in the B1 position, a second set of inducible $\kappa \mathrm{B}$-enhancer-binding proteins have been identified in T cells, namely p50 and p85 (c-rel) $(20,21)$. These proteins, in contrast to $\mathrm{p} 55$ and $\mathrm{p} 75$, are only expressed in the nucleus of PMA-stimulated Jurkat $\mathrm{T}$ cells after $\geq 4 \mathrm{~h}$ of stimulation. Although these proteins, like p55 (NF- $\kappa$ B p50) and p75 (NF- $\mathrm{B}$ p65), are preformed and sequestered in the cytoplasm of resting $T$ cells by either $I_{\kappa} B$ or a related inhibitor, a significant component of the late induction of these factors depends upon increased mRNA expression and de novo protein synthesis (Molitor, J., and W. C. Greene, unpublished data). Based on proteolytic mapping studies, the p50 polypeptide appears to be very closely related to $\mathrm{NF}-\kappa \mathrm{B} p 50$, perhaps corresponding to a large proteolytic fragment or alternatively spliced gene product (20).

In the present study, we have identified four important differences in the pattern of expression of these four $\kappa$ B enhancerbinding proteins in human U937 and THP-1 monocytic cells compared with that previously reported in human Jurkat $T$ cells. First, in both U937 and THP-1 monocytic cells, NF- $\kappa$ B p50 and the related protein comprising the p50 crosslinked adduct are constitutively expressed in the nucleus in the near or complete absence of p75 (NF- $\kappa$ B p65) and p85 (c-Rel). This finding stands in contrast to their inducible pattern of expression found in Jurkat $T$ cells. Second, nuclear expression of NF- $\kappa$ B p 65 in these monocytic cells requires cellular activation by such agents as TNF $\alpha$ or PMA. Third, little p85 (c-rel) expression is found in either of these monocytic cell lines. This finding may reflect a generally lymphoid-restricted pattern of c-rel gene expression. Fourth, our kinetic experiments of p75 (NF- $\kappa \mathrm{B}$ p65) and $\mathrm{p} 55$ (NF- $\mathrm{B}$ p50) induction by PMA in both U937 and THP-1 cells demonstrate markedly slower kinetics in these monocytic cells than that previously found in Jurkat $T$ cells, where these proteins are readily detected in the nucleus within 20 min of PMA stimulation (20). Specifically, PMA induction of $\mathrm{p} 75$ requires $2-4 \mathrm{~h}$ of stimulation, and although a slight induction of $\mathrm{p} 55$ above its constitutive level is noted at 20 min after PMA stimulation, the level of induction is markedly increased after $4 \mathrm{~h}$ (Fig. $6 \mathrm{~B}$ ). In sharp contrast, TNF $\alpha$ activation leads to the rapid nuclear expression of these proteins in these monocytic cells. Interestingly, TNF $\alpha$ activation of Jurkat $\mathrm{T}$ cells leads to similarly rapid kinetics of induction of these same proteins (Molitor, J., and W. C. Greene, unpublished observations). PMA may thus inefficiently mobilize the preformed pool of NF- $\kappa \mathrm{B} p 50$ and NF- $\kappa \mathrm{B}$ p 65 sequestered by $\mathrm{I}_{\kappa} \mathrm{B}$ in the cytoplasm of these monocytic cell lines, whereas TNF $\alpha$ appears to readily liberate these preformed factors. These findings thus suggest fundamentally different mechanisms of TNF $\alpha$ and PMA induction of these proteins in these monocytic cells. In this regard, Osborn et al. (9) independently suggested that the TNF $\alpha$ induction of NF- $\kappa$ B in T cells may occur via a mechanism distinct from that of PMA induction of NF$\kappa B$ in these cells. Further, Hohmann et al. (51) recently reported a similar phenomenon of rapid TNF $\alpha$ induction and delayed PMA induction of NF- $\mathrm{KB}$ in the HL- 60 myelomonocytic cell line. Preliminary Northern blot analyses that we have performed in fact suggest that PMA induces increased expression of NF- $\kappa$ B p105 mRNA (the precursor of NF- $\kappa$ B p50) in human monocytic cells.

Our findings appear to differ from those of Griffin et al. (52), who reported that U937 cells do not constitutively express any $\kappa \mathrm{B}$-enhancer-binding proteins whereas THP-1 cells do. In part, these differences may be due to different U937 subclones used in the two studies. Alternatively, these differences may in part be due to the different assay systems used. These authors also reported that PMA induction of THP-1 cells failed to lead to an activation of transfected HIV-1 LTR CAT reporter constructs above the high constitutive background of expression. 
They concluded that NF- $\mathrm{KB}$ induction in U937 cells was dependent upon cellular differentiation and that the constitutive expression of NF- $\kappa$ B in THP-1 cells reflected its more mature, or differentiated, phenotype. Our data certainly do not exclude a possible role for cellular differentiation in the regulation of $\mathrm{NF}-\kappa \mathrm{B}$ p50 and NF- $\kappa \mathrm{B}$ p 65 . In fact, our findings of increased constitutive HIV-1 LTR CAT activity and low level B1 complex formation in the relatively mature THP-1 cells support the idea that differentiation of monocytes may play a role in the expression of these proteins. However, the present demonstration of the constitutive nuclear expression of the proteins comprising the p50 and p55 crosslinked adducts in immature U937 cells both confirms and extends the earlier studies of Lubon et al. (53) and Collart et al. (54) and demonstrates that differentiation is not a prerequisite for NF- $\kappa \mathrm{B}$ p50 expression in these monocytic cells. Furthermore, our finding that TNF $\alpha$ activation of U937 cells leads to the extremely rapid induction of the nuclear expression of NF- $\kappa$ B p50 and NF- $\kappa$ B p 65 also demonstrates that differentiation of these immature U937 cells is not a prerequisite for the nuclear expression of NF- $\kappa \mathrm{B} p 50$ or NF- $\kappa \mathrm{B}$ p65. Finally, our finding that both NF- $\kappa B$ p 50 and NF- $\kappa B$ p 65 are markedly inducible in the more differentiated THP-1 cells suggests that cellular activation rather than cellular differentiation probably plays the dominant role in the regulated expression of these proteins in monocytic cells. In many respects these monocytic cells exhibit a phenotype of $\kappa \mathrm{B}$ enhancerbinding protein expression intermediate between that of mature $B$ cells and most $T$ cells. In many mature B cell populations, both NF- $\kappa$ B p50 and NF- $\kappa$ B p 65 are constitutively expressed whereas in most $\mathrm{T}$ cell lines examined neither of these NF- $\kappa$ B subunits are constitutively expressed in the nucleus.

The induction of p75 (NF- $\kappa \mathrm{B}$ p65) and increased expression of p55 (NF- $k \mathrm{~B} \mathrm{p50)}$ occurring after TNF $\alpha$ or PMA stimulation of these monocytic cells appears functionally important, as activity of the HIV-1 LTR is coordinately induced 5-10-fold in a $\kappa$ B enhancer-dependent manner in both U937 and THP-1 cells. These findings agree with the recent studies of Pomerantz et al. (55), who have described activation of the HIV-1 LTR by PMA + PHA, TNF $\alpha$, or LPS in both U937 and THP-1 cells. These results are consistent with our recent studies demonstrating that NF- $\kappa$ B p65, but not NF- $\kappa$ B p50, contains a potent transcriptional activator domain (27). Thus, as with $\mathrm{T}$ cells, the state of monocytic cell activation importantly determines $\kappa B$ enhancer-binding protein expression and significantly contributes to the overall state of HIV-1 gene expression. These findings suggest that cellular stimuli that induce the nuclear expression of NF- $\kappa$ B p65 in monocytes in vivo may significantly contribute to the activation of HIV-1 replication.

\section{Acknowledgments}

Peter A. Kaufman is supported by a Physician Scientist Award (5 K11 CA01458-02).

\section{References}

1. Cullen, B. R., and W. C. Greene. 1989. Regulatory pathways governing HIV-1 replication. Cell. 58:423-426.

2. Ho, D. D., T. R. Rota, and M. S. Hirsch. 1986. Infection of monocyte/ macrophages by human T lymphotropic virus type III. J. Clin. Invest. 77:17121715.

3. Ho, D. D., R. J. Pomerantz, and J. C. Kaplan. 1987. Pathogenesis of infection with human immunodeficiency virus. N. Engl. J. Med. 317:278-286.
4. Fauci, A. S. 1988. The human immunodeficiency virus: infectivity and mechanisms of pathogenesis. Science (Wash. DC). 239:617-622.

5. Greene, W. C. 1991. The molecular biology of human immunodeficiency virus type I infection. N. Engl. J. Med. 324:308-316.

6. Wiley, C. A., R. D. Schrier, J. A. Nelson, P. W. Lampert, and M. B. Oldstone. 1986. Cellular localization of HIV infection within brains of AIDS patients. Proc. Natl. Acad. Sci. USA. 83:7089-7093.

7. Nabel, G., and D. Baltimore. 1987. An inducible transcription factor activates expression of human immunodeficiency virus in T cells. Nature (Lond.). 326:711-713.

8. Böhnlein, E., J. W. Lowenthal, M. Siekevitz, D. W. Ballard, B. R. Franza, and W. C. Greene. 1988. The same inducible nuclear proteins regulates mitogen activation of both the interleukin-2 receptor alpha gene and type $1 \mathrm{HIV}$. Cell. 53:827-836.

9. Osborn, L., S. Kunkel, and G. J. Nabel. 1989. Tumor necrosis factor $\alpha$ and interleukin 1 stimulate the human immunodeficiency virus enhancer by activation of the nuclear factor $\kappa$ B. Proc. Natl. Acad. Sci. USA. 86:2336-2340.

10. Folks, T. M., K. A. Clouse, J. Justement, A. Rabson, E. Duh, J. H. Kehrl, and A. S. Fauci. 1989. Tumor necrosis factor $\alpha$ induces expression of human immunodeficiency virus in a chronically infected T cell clone. Proc. Natl. Acad. Sci. USA. 86:2365-2368.

11. Sen, R., and D. Baltimore. 1986. Multiple nuclear factors interact with the immunoglobulin enhancer sequences. Cell. 46:705-716.

12. Atchison, M. L., and R. P. Perry. 1987. The role of the $\kappa$ enhancer and its binding factor NF- $\kappa \mathrm{B}$ in the developmental regulation of $\kappa$ gene transcription. Cell. 48:121-128.

13. Leung, K., and G. J. Nabel. 1988. HTLV-1 transactivator induces interleukin-2 receptor expression through an NF-кB like factor. Nature (Lond.). 333:776-778.

14. Ballard, D. W., E. Böhnlein, J. W. Lowenthal, Y. Wano, B. R. Franza, and W. C. Greene. 1988. HTLV-I tax induces cellular proteins that activate the $\kappa B$ element in the IL-2 receptor $\alpha$ gene. Science (Wash. DC). 241:1652-1655.

15. Ballard, D. W., E. Böhnlein, J. A. Hoffman, H. P. Bogerd, E. P. Dixon, B. R. Franza, and W. C. Greene. 1989. Activation of the interleukin-2 receptor $\alpha$ gene: regulatory role for DNA-protein interactions flanking the $\kappa \mathrm{B}$ enhancer. New Biol. 1:83-92.

16. Hoyos, B., D. W. Ballard, E. Böhnlein, M. Siekevitz, and W. C. Greene. 1989. Kappa B specific DNA binding proteins: role in the regulation of human interleukin-2 gene expression. Science (Wash. DC). 244:457-460.

17. Miyatake, S., M. Seiki, M. Yoshida, and K. Arai. 1988. T-cell activation signals and human T-cell leukemia virus type I encoded $p 40 x$ protein activate the mouse granulocyte-macrophage colony-stimulating factor gene through a common DNA element. Mol. Cell. Biol. 8:5581-5587.

18. Schreck, R., and P. A. Baeuerle. 1990. NF- $\kappa$ B as inducible transcriptional activator of the granulocyte-macrophage colony-stimulating factor gene. $\mathrm{Mol}$. Cell. Biol. 10:1281-1286.

19. Paul, N. L., M. J. Lenardo, K. D. Novak, T. Sarr, W. L. Tang, and N. H. Ruddle. 1990. Lymphotoxin activation by human T-cell leukemia virus type I-infected cell lines: role for NF-kappa B. J. Virol. 64:5412-5419.

20. Molitor, J. A., W. H. Walker, S. Doerre, D. W. Ballard, and W. C. Greene. 1990. NF- $\kappa$ B: a family of inducible and differentially expressed enhancer-binding proteins in human T cells. Proc. Natl. Acad. Sci. USA. 87:10028-10032.

21. Ballard, D. W., W. H. Walker, S. Doerre, P. Sista, J. A. Molitor, E. P. Dixon, N. J. Peffer, M. Hannink, and W. C. Greene. 1990. The v-rel oncogene encodes a $\kappa \mathrm{B}$ enhancer binding protein that inhibits NF- $\kappa \mathrm{B}$ function. Cell. 63:803-814.

22. Kawakami, K., C. Scheidereit, and R. Roeder. 1988. Identification and purification of a human immunoglobulin enhancer-binding protein (NF- $\kappa$ B) that activates transcription from a human immunodeficiency virus type I promoter in vitro. Proc. Natl. Acad. Sci. USA 85:4700-4704.

23. Lenardo, M. J., A. Kuang, A. Gifford, and D. Baltimore. 1988. NF-kappa B protein purification from bovine spleen: nucleotide stimulation and binding site specificity. Proc. Natl. Acad. Sci. USA. 85:8825-8829.

24. Baeuerle, P., and D. Baltimore. 1988. Activation of DNA-binding activity in an apparently cytoplasmic precursor of the NF- $\mathrm{BB}$ transcription factor. Cell. 53:211-217.

25. Baeuerle, $P$., and D. Baltimore. 1989. A $65-k D$ subunit of active NF- $\kappa B$ is required for inhibition of NF-кB by IкB. Genes \& Dev. 3:1689-1698.

26. Nolan, G. P., S. Ghosh, H. Liou, P. Tempst, and D. Baltimore. 1991. DNA binding and $I_{\kappa} B$ inhibition of the cloned p 65 subunit of NF- $\kappa \mathrm{B}$, a rel-related polypeptide. Cell. 64:961-969.

27. Ballard, D. W., E. P. Dixon, N. J. Peffer, H. Bogerd, S. Doerre, and W. C. Greene. 1992. The $65 \mathrm{kD}$ subunit of human NF- $\kappa$ B functions as a potent transcriptional activator and a target v-rel mediated repression. Proc. Natl. Acad. Sci. USA. 89:1875-1879.

28. Ruben, S. M., P. J. Dillon, R. Schreck, T. Henkel, C. Chen, M. Maher, P. A. Baeuerle, and C. A. Rosen. 1991. Isolation of a rel-related human cDNA that potentially encodes the 65-kD subunit of NF-кB. Science (Wash. DC). 251:1490-1493. 
29. Ghosh, S., A. M. Gifford, L. R. Riviere, P. Tempst, G. P. Nolan, and D. Baltimore. 1990. Cloning of the p50 DNA binding subunit of NF- $\kappa$ B: homology to rel and dorsal. Cell. 62:1019-1029.

30. Kieran, M., V. Blank, F. Logeat, J. Vandekerckhove, F. Lottspeich, O. Le Bail, M. B. Urban, P. Kourilsky, P. A. Baeuerle, and A. Israël. 1990. The DNA binding subunit of NF- $\kappa \mathrm{B}$ is identical to factor $\mathrm{KBF} 1$ and homologous to the rel oncogene product. Cell. 62:1007-1018.

31. Baeuerle, P., and D. Baltimore. 1988. I $\kappa$ B: a specific inhibitor of the NF- $\kappa$ B transcription factor. Science (Wash. DC). 242:540-546.

32. Ghosh, S., and D. Baltimore. 1990. Activation in vitro of NF- $\kappa$ B by phosphorylation of its inhibitor IkB. Nature (Lond.). 344:678-682.

33. Sundstron, C., and K. Nillsson. 1976. Establishment and characterization of a human histiocytic lymphoma cell line (U937). Int. J. Cancer. 17:565-577.

34. Tsuchiya, S., M. Yamabe, Y. Yamaguchi, Y. Kobayashi, T. Konno, and K. Tada. 1980. Establishment and characterization of a human acute monocytic leukemia cell line (THP-1). Int. J. Cancer. 26:171-176.

35. Auwerx, J. 1991. The human leukemia cell line, THP-1: a multifaceted model for the study of monocyte-macrophage differentiation. Experientia ( $\mathrm{Ba}$ sel). 47:22-31.

36. Dignam, J., R. Lebovitz, and R. G. Roeder. 1983. Accurate transcription initiation by RNA polymerase II in a soluble extract from isolated mammalian nuclei. Nucleic Acids Res. 11:1475-1489.

37. Dynan, W. C. 1987. DNase I footprinting as an assay for mammalian gene regulatory proteins. In Genetic Engineering: Principles and Methods. J. K. Setlow, editor. Plenum Press, New York. 75-87.

38. Wu, C., S. Wilson, B. Walker, L. David, T. Paisley, V. Zimarino, and H. Ueda. 1987. Purification and properties of Drosophila heat shock activator protein. Science (Wash. DC). 238:1247-1253.

39. Stein, B., M. Krämer, H. J. Rahmsdorf, H. Ponta, and P. Herrlich. 1989. UV-induced transcription from the human immunodeficiency virus type 1 (HIV1) long terminal repeat and UV-induced secretion of an extracellular factor that induces HIV-1 transcription in nonirradiated cells. J. Virol. 63(11):4540-4544.

40. Holbrook, N., A. Gulino, and F. Ruscetti. 1987. Cis-acting transcriptional regulatory sequences in the gibbon ape leukemia virus (GALV) long terminal repeat. Virology. 157:211-219.

41. Neumann, J. F., C. Morency, and K. Russian. 1987. A novel rapid assay for chloramphenicol acetyltransferase gene expression. Biotechniques. 5:444447.

42. Bradford, M. 1976. A rapid and sensitive method for the quantitation of microgram quantities of protein utilizing the principle of protein-dye binding. Anal. Biochem. 72:248-254.

43. Jones, K. A., J. T. Kadonaga, P. A. Luciw, and R. Tjian. 1986. Activation of the AIDS retrovirus promoter by the cellular transcription factor, Spl. Science (Wash. DC). 232:755-759.

44. Michie, H. R., K. R. Manogue, D. R. Spriggs, A. Revhaug, S. O'Dwyer, C. A. Dinarello, A. Cerami, S. M. Wolff, and D. W. Wilmore. 1988. Detection of circulating tumor necrosis factor after endotoxin administration. N. Engl. J. Med. 318:1481-1486.

45. Cannon, J. G., R. G. Tompkins, J. A. Gelfand, H. R. Michie, G. G. Stanford, J. W. M. van der Meer, S. Endres, G. Lonnemann, J. Corsetti, B. Chernow, et al. 1990. Circulating interleukin-1 and tumor necrosis factor in septic shock and experimental endotoxin fever. J. Infect. Dis. 161:79-84.

46. Ruben, S., H. Poteat, T. Tan, K. Kawakami, R. Roeder, W. Haseltine, and C. A. Rosen. 1988. Cellular transcription factors and regulation of IL-2 receptor gene expression by HTLV-I tax gene product. Science (Wash. DC). 241:89-92.

47. Sen, R., and D. Baltimore. 1986. Inducibility of $\kappa$ immunoglobulin enhancer-binding protein NF- $\kappa$ B by a posttranslational mechanism. Cell. 47:921928.

48. Lenardo, M. J., and D. Baltimore. 1989. NF-кB: a pleiotropic mediator of inducible and tissue-specific gene control. Cell. 58:227-229.

49. Böhnlein, E., D. W. Ballard, H. Bogerd, N. J. Peffer, J. W. Lowenthal, and W. C. Greene. 1989. Induction of interleukin-2 receptor- $\alpha$ gene expression is regulated by post-translational activation of $\kappa \mathrm{B}$ specific DNA binding proteins. $J$. Biol. Chem. 264:8475-8478.

50. Lowenthal, J. W., D. W. Ballard, H. Bogerd, E. Böhnlein, and W. C. Greene. 1989. Tumor necrosis factor-alpha activation of the IL-2 receptor-alpha gene involves the induction of $\kappa \mathrm{B}$-specific DNA binding proteins. J. Immunol. 142:3121-3128.

51. Hohmann, H. P., R. Remy, C. Scheidereit, and A. P. Van Loon. 1991 Maintenance of NF- $\mathrm{kB}$ activity is dependent on protein synthesis and the continuous presence of external stimuli. Mol. Cell. Biol. 11(1):259-266.

52. Griffin, G. E., K. Leung, T. M. Folks, S. Kunkel, and G. J. Nabel. 1989. Activation of HIV gene expression during monocyte differentiation by induction of NF-кB. Nature (Lond.). 339:70-73.

53. Lubon, H., P. Ghazal, J. A. Nelson, and L. Hennighausen. 1988. Cell-specific activity of the human immunodeficiency virus enhancer repeat in vitro. AIDS Res. Hum. Retroviruses 4:381-391.

54. Collart, M. A., P. Baeuerle, and P. Vassalli. 1990. Regulation of tumor necrosis factor alpha transcription in macrophages: involvement of four $\kappa \mathrm{B}$-like motifs and of constitutive and inducible forms of NF-кB. Mol. Cell. Biol. 10:1498-1506.

55. Pomerantz, R. J., M. B. Feinberg, D. Trono, and D. Baltimore. 1990 Lipopolysaccharide is a potent monocyte/macrophage specific stimulator of human immunodeficiency virus type 1 expression. J. Exp. Med. 172:253-261. 